\title{
PENGETAHUAN GIZI IBU YANG MEMILIKI ANAK USIA BAWAH DUA TAHUN STUNTING DI KELURAHAN CIMAHI (MOTHER'S NUTRITION KNOWLEDGE FOR TODDLERS STUNTING IN CIMAHI VILLAGE)
}

\author{
Anisa Putri Isnarti ${ }^{1}$, Ai Nurhayati ${ }^{1}$, Rita Patriasih ${ }^{1}$ \\ Program Studi Pendidikan Tata Boga, Departemen Pendidikan Kesejahteraan \\ Keluarga, Fakultas Pendidikan Teknologi dan Kejuruan, Universitas Pendididkan \\ Indonesia
}

anisaputriisnarti@gmail.com

\begin{abstract}
Abstrak: Anak usia bawah dua tahun di Kelurahan Cimahi mengalami kasus gizi stunting sebanyak $7.72 \%$. Salah satu faktor penyebab anak mengalami stunting adalah tingkat pengetahuan gizi ibu yang rendah. Tujuan dalam penelitian untuk mengetahui pengetahuan gizi ibu yang memiliki anak usia bawah dua tahun stunting di Kelurahan Cimahi. Metode yang digunakan yaitu metode deksriptif. Populasi sebanyak 246 orang ibu yang memiliki anak usia bawah dua tahun. Sampel purposive digunakan sebanyak 40 orang ibu yang memiliki anak usia bawah dua tahun stunting. Hasil penelitian mengungkapkan bahwa pengetahuan gizi ibu yaitu sebanyak $60 \%$ memiliki pengetahuan gizi cukup, $27.5 \%$ memiliki pengetahuan gizi kurang, dan $12.5 \%$ memiliki pengetahuan gizi baik dengan rata-rata st.dev $\pm 3,7$ pada pengetahuan tersebut. Rekomendasi ditunjukkan kepada kader posyandu untuk melakukan pendampingan lebih intensif terhadap ibu yang memiliki anak usia bawah dua tahun stunting, pendampingan yang dilakukan oleh kader tidak hanya saat kegiatan posyandu berlangsung agar pengetahuan gizi ibu menjadi lebih baik.
\end{abstract}

Kata kunci: pengetahuan gizi ibu, anak usia bawah dua tahun, stunting

\section{PENDAHULUAN}

Kelurahan Cimahi merupakan salah satu kelurahan yang ada di Kecamatan Cimahi Tengah, Kota Cimahi yang mengalami kasus gizi stunting pada anak usia bawah dua tahun. Berdasarkan data yang diperoleh dari Puskesmas Cimahi Tengah, pada tahun 2018 terdapat sebanyak 53 anak usia bawah dua tahun (baduta) atau sebanyak 7,72\% dengan rentang usia 6-23 bulan mengalami kasus gizi stunting (tinggi badan pendek). Stunting (pendek) merupakan salah satu masalah kurang gizi kronis pada anak baduta usia 0-24 bulan yang disebabkan oleh asupan gizi yang kurang dalam rentang waktu yang cukup lama akibat pemberian asupan makanan yang tidak sesuai dengan kebutuhan gizi.

Stunting dapat diketahui dengan mengukur indeks Panjang Badan menurut Umur (PB/U) atau Tinggi Badan menurut Umur (TB/U) (Kemenkes, 2016). Salah satu faktor penyebab anak bawah dua tahun stunting adalah tingkat pengetahuan gizi orang tua yang masih rendah. Pengetahuan gizi adalah kemampuan seseorang untuk mengingat kembali kandungan gizi makanan serta kegunaan zat gizi tersebut dalam tubuh.

Pengetahuan gizi yang harus dimiliki ibu antara lain kebutuhan gizi bagi tubuh seperti karbohidrat, protein, lemak, vitamin, dan mineral. Selain itu, jenis-jenis makanan sehari-hari 
yang mengandung zat gizi dan memiliki fungsi bagi tubuh, serta dampak atau penyakit - penyakit yang disebabkan oleh kekurangan gizi (Notoatmodjo dalam Tanti Marina, 2013).

Penelitian ini bertujuan untuk mengetahui pengetahuan gizi ibu yang memiliki anak usia bawah dua tahun stunting di Kelurahan Cimahi.

\section{METODE}

Penelitian ini menggunakan desain cross-sectional dengan metode penelitian deskriptif. Penelitian dilaksanakan selama 8 bulan yaitu mulai Januari 2019 - Agustus 2019 di Kelurahan Cimahi, Kecataman Cimahi Tengah, Kota Cimahi, Provinsi Jawa Barat.

Populasi dalam penelitian merupakan seluruh ibu yang memiliki anak bawah dua tahun dengan rentang usia 6 - 23 bulan yaitu sebanyak 246 orang. Pengambilan sample menggunakan teknik sampel purposive dan terdapat 40 orang ibu yang memiliki anak usia bawah dua tahun dengan kriteria : (a) ibu yang berada di lingkungan Kelurahan Cimahi, (b) memiliki anak usia bawah dua tahun yang mengalami kasus stunting, (c) memiliki anak usia bawah dua tahun dengan rentang 6-23 bulan.

Data yang dikumpulkan meliputi nama responden, umur, tingkat pendidikan orang tua, dan tingkat pengetahuan gizi ibu

Tabel 1. Pengelompokkan tingkat pengetahuan gizi ibu

\begin{tabular}{cc}
\hline $\begin{array}{c}\text { tingkat } \\
\text { pengetahuan gizi }\end{array}$ & kelompok \\
\hline $81 \%-100 \%$ & Sangat baik \\
$66 \%-80 \%$ & Baik \\
$51 \%-65 \%$ & Cukup \\
$0 \%-50 \%$ & Kurang \\
\hline
\end{tabular}

\section{HASIL DAN PEMBAHASAN}

Kelurahan Cimahi merupakan salah satu kelurahan yang terletak di Kota Cimahi yang memiliki sebanyak sepuluh rukun warga yang tersebar di kelurahan tersebut. Pada tahun 2018, Kota Cimahi merupakan salah satu kota yang mengalami permasalahan stunting dengan prevalensi $27,78 \%$. Kelurahan Cimahi yang terletak di wilayah Kecamatan Cimahi Tengah yang menjadi lokasi penelitian memiliki prevalensi anak usia bawah tahun stunting sebesar 7,72\% berdasarkan Laporan Hasil Penimbangan Balita Kelurahan Cimahi (2018). Adapun, karakteristik responden ibu seperti yang disajikan pada Tabel 2.

Tabel 2. Karakteristik Responden

\begin{tabular}{lcc}
\hline \multicolumn{1}{c}{ Variabel } & $\mathrm{n}$ & $\%$ \\
\hline Usia ibu & & \\
$20-25$ tahun & 5 & 12 \\
$26-30$ tahun & 8 & 20 \\
$31-35$ tahun & 10 & 25 \\
$36-40$ tahun & 17 & 43 \\
\hline Pendidikan terakhir ibu & & \\
SD & 3 & 7 \\
SMP & 6 & 15 \\
SMA / SMK & 28 & 70 \\
D3/S1 & 2 & 8 \\
\hline
\end{tabular}

Sampel penelitian di Kelurahan Cimahi kategori umur ibu paling banyak terdapat pada rentang usia $36-$ 40 tahun yaitu sebanyak $43 \%$. Dapat dilihat bahwa ibu yang berusia 34-40 tahun lebih banyak dibandingkan dengan yang lain, seharusnya semakin dewasa usia maka tingkat kemampuan dan kematangan dalam berfikir dan menerima informasi lebih baik. Usia juga merupakan faktor penentu dalam tingkat pengetahuan, pengalaman, keyakinan, dan motivasi sehingga 
umur dapat mempengaruhi perilaku seseorang terhadap objek tertentu.

Sampel penelitian di Kelurahan Cimahi kategori pendidikan formal ibu paling banyak terdapat pada tingkat pendidikan SMA/SMK yaitu sebanyak 70\%. Pendidikan formal ibu seharusnya dapat mempengaruhi tingkat pengetahuan yang berhubungan dengan gizi, dimana seharusnya semakin tinggi tingkat pengetahuan ibu semakin tinggi pula ibu dapat menyerap pengetahuan gizi dalam lingkungan formal maupun non formal terutama melalui media massa. Hal tersebut sejalan dengan penelitian yang dilakukan oleh Tiwari et al (2014) di Nepal, yang menunjukkan bahwa tingkat pendidikan formal ibu merupakan faktor risiko terjadinya stunting pada anak usia bawah dua tahun. Adapun hasil penelitian yang dilakukan oleh Nasikhah (2012) yang mengemukakan bahwa tingkat pendidikan ibu adalah faktor kejadian stunting yang tidak bermakna. Tingkat pendidikan ibu yang tidak bermakna diduga terkait dengan status perkerjaan ibu, dimana ibu yang berpendidikan tinggi biasanya memiliki pekerjaan.

Pengetahuan merupakan suatu landasan berfikir manusia dalam melakukan suatu hal yang berkaitan dengan pencarian jawaban atas pertanyaan yang ada Surjaweni (2014). Dalam hal ini terdapat hasil tingkat pengetahuan ibu mengenai gizi di Kelurahan Cimahi yang meliputi pengetahuan jenis-jenis dan fungsi zat gizi, sumber-sumber zat gizi, anjuran makan sehari berdasarkan $\mathrm{AKG}$, dan dampak kekurangan gizi bagi anak usia bawah dua tahun yang disajikan pada Tabel berikut ini:
Tabel 3. Pengetahuan Jenis-Jenis dan Fungzi Zat Gizi Bagi Anak Usia Bawah Dua Tahun

\begin{tabular}{lcc}
\hline Tingkat Pengetahuan & $\mathrm{n}$ & $\%$ \\
\hline Kurang & 27 & 67,5 \\
Cukup & 7 & 17,5 \\
Baik & 5 & 12,5 \\
Sangat Baik & 1 & 2,5 \\
\hline \multicolumn{2}{c}{ Pengetahuan jenis-jenis } &
\end{tabular}
fungsi zat gizi untuk anak usia bawah dua tahun berdasarkan distribusi kategori pengetahuan, lebih dari setengah $(67.5 \%)$ pengetahuan ibu termasuk pada kategori kurang. Pengetahuan gizi ibu merupakan salah satu faktor tidak langsung yang dapat menyebabkan anak menjadi stunting. Ibu dengan pengetahuan gizi yang kurang akan berpengaruh pada pemberian makanan dan pengetahuan mengenai jenis serta fungsi zat gizi untuk anak. Hal tersebut sejalan dengan pendapat yang dikemukakan oleh Ni'mah (2015) yang menyatakan bahwa sebanyak $61.8 \%$ pengetahuan ibu mengenai gizi di wilayah Puskesmas Tanah Kali Kedinding Surabaya masih rendah dan rendahnya pengetahuan merupakan salah satu faktor yang berhubungan dengan kejadian stunting.

Tabel 4. Pengetahuan Sumber-Sumber Zat Gizi Bagi Anak Usia Bawah Dua Tahun

\begin{tabular}{lcc}
\hline Tingkat Pengetahuan & $\mathrm{n}$ & $\%$ \\
\hline Kurang & 5 & 12,5 \\
Cukup & 6 & 15 \\
Baik & 21 & 52,5 \\
Sangat Baik & 8 & 20 \\
\hline
\end{tabular}

Pengetahuan sumber-sumber zat gizi bagi anak usia bawah dua tahun berdasarkan distribusi, kategori pengetahuan tersebut setengah $(52.5 \%)$ ibu termasuk kedalam kategori baik. Pengetahuan mengenai 
sumber-sumber zat gizi dapat berpengaruh pada kesadaran ibu dalam pemberian asupan gizi bagi anak. Adapun, pengaruh lain apabila ibu sudah memahami pengetahuan mengenai sumber-sumber zat gizi adalah ibu dapat mengaplikasikan pengetahuan tersebut dalam kehidupan sehari-hari seperti dapat menyediakan dan menyajikan makanan begizi untuk anak dengan memperhatikan keanekaragaman bahan makanan sumber zat gizi agar anak terhindar dari stunting. Hal tersebut sejalan dengan penelitian yang dilakukan oleh Laraeni, dkk (2015) yang mengemukakan bahwa tingkat pengetahuan ibu mengenai sumber zat gizi seperti sumber karbohidrat dan protein berada pada kategori cukup yaitu sebanyak $78 \%$ dimana ibu mengetahui bahwa sumber karbohidrat dan sumber protein diperlukan untuk membantu proses pertumbuhan anak agar tercegah dari stunting.

Tabel 5. Pengetahuan Anjuran Makan Sehari Berdasarkan Angka Kecukupan

Gizi Bagi Anak Usia Bawah Dua Tahun

\begin{tabular}{lcc}
\hline Tingkat Pengetahuan & $\mathrm{n}$ & $\%$ \\
\hline Kurang & 29 & 72,5 \\
Cukup & 4 & 10 \\
Baik & 6 & 15 \\
Sangat Baik & 1 & 2,5 \\
\hline
\end{tabular}

Pengetahuan anjuran makan sehari berdasarkan angka kecupan gizi bagi anak usia bawah dua tahun berdasarkan distribusi, kategori pengetahuan tersebut lebih dari setengah $(72.5 \%)$ ibu memiliki tingkat pengetahuan dengan kategori kurang. Hal tersebut menandakan ibu belum memahami pengetahuan mengenai anjuran makan sehari berdasarkan angka kecupan gizi bagi anak usia bawah dua tahun. Manfaat yang didapatkan apabila ibu mengetahui anjuran makan berdasarkan AKG adalah ibu dapat mengetahui banyaknya jumlah zat-zat gizi yang dibutuhkan anak usia bawah dua tahun untuk mempertahankan status gizinya agar tidak mengalami stunting. Watania (2016) mengemukakan pengetahuan gizi ibu yang keliru dapat mempengaruhi kebiasaan ibu dalam pemberian makanan yang keliru dengan porsi yang tidak teratur dan tepat akan menyebabkan anak usia bawah dua tahun menjadi stunting. Hal tersebut sejalan dengan penelitian yang dilakukan oleh Wahyuni (2011) bahwa sebagian besar responden $(45 \%)$ di daerah Pereng Yogyakarta mempunyai tingkat pengetahuan yang kurang tentang MP-ASI seperti karbohidrat, protein, lemak, vitamin dan mineral sehingga hal tersebut dapat berpengaruh terhadap pengetahuan responden mengenai kesesuaian porsi anjuran makan untuk anak.

Tabel 6. Dampak Kekurangan Gizi

Bagi Anak Usia Bawah Dua Tahun

\begin{tabular}{lcc}
\hline Tingkat Pengetahuan & $\mathrm{n}$ & $\%$ \\
\hline Kurang & 7 & 17,5 \\
Cukup & 10 & 25 \\
Baik & 12 & 30 \\
Sangat Baik & 11 & 27,5 \\
\hline
\end{tabular}

Pengetahuan dampak kekurangan gizi bagi anak usia bawah dua tahun berdasarkan distribusi, kategori pengetahuan tersebut kurang dari setengah $(30 \%)$ ibu memiliki tingkat pengetahuan gizi dengan kategori baik. Kekurangan gizi menimbulkan masalah status gizi pada seseorang atau individu. Salah satu dampak kekurangan gizi pada anak adalah stunting. Hal tersebut sejalan dengan penelitian Ramlah (2014) yang mengemukakan bahwa tingkat 
pengetahuan ibu mengenai faktor penyebab stunting berada pada kategori cukup yaitu sebesar $45.9 \%$. Anak yang mengalami stunting akan memiliki resiko ketika ia memasuki usia dewasa, masalah tersebut adalah meningkatkan resiko masalah kesehatan (penyakit degeneratif) saat dewasa.

Pengetahuan ibu tentang gizi yang meliputi pengetahuan jenis dan fungsi zat gizi bagi anak usia bawah dua tahun, sumber-sumber zat gizi bagi anak usia bawah dua tahun, anjuran makan sehari berdasarkan angka kecukupan gizi bagi anak usia bawah dua tahun, dan dampak kekurangan gizi bagi anak usia bawah dua tahun, diuraikan pada Tabel sebagai berikut:

Tabel 7. Tingkat Pengetahuan Gizi Ibu

\begin{tabular}{lcc}
\hline Tingkat Pengetahuan & $\mathrm{n}$ & $\%$ \\
\hline Kurang & 11 & 27,5 \\
Cukup & 24 & 60 \\
Baik & 5 & 12,5 \\
Sangat Baik & 0 & 0 \\
\hline
\end{tabular}

Tingkat pengetahuan ibu di Kelurahan Cimahi, mengenai pengetahuan gizi berada dalam kategori cukup yaitu $60 \%$.

Pengetahuan gizi ibu berperan dalam penentuan pertumbuhan dan perkembangan anak dilihat dari status gizi anak salah satunya adalah stunting. Tingkat pengetahuan gizi merupakan faktor yang berhubungan dengan kejadian stunting pada penelitian ini. Pendapat Hanum, dkk (2014) yang mengemukakan bahwa ibu yang berada di desa Batulawang, Kabupaten Cianjur berdasarkan ratarata skor pengetahuan gizi, sebanyak $38.3 \%$ ibu yang memiliki anak stunting memiliki tingkat pengetahuan gizi termasuk dalam kategori rendah. Hal tersebut berbeda dengan hasil pengetahuan gizi ibu di Kelurahan
Cimahi, dimana pengetahuan gizi ibu sebanyak $60 \%$ ibu yang memiliki anak stunting memiliki tingkat pengetahuan gizi termasuk dalam kategori cukup.

Pengetahuan gizi ibu yang baik akan menyebabkan seseorang mampu menyusun dan mengatur menu yang baik untuk dikonsumsi, berbelanja, memasak, menyiapkan makanan, dan mendistribusikan makanan yang baik untuk dikonsumsi oleh anak usia bawah dua tahun agar ibu dapat mencegah stunting pada anak, sehingga masalah stunting tidak berkelanjutan.

\section{KESIMPULAN}

Pengetahuan ibu terkait pengetahuan gizi di Kelurahan Cimahi berada dalam kategori cukup, dengan persentase pengetahuan yaitu lebih dari setengah ibu memiliki pengetahuan gizi pada kriteria cukup, kurang dari setengah ibu memiliki pengetahuan gizi pada kriteria kurang dan sebagian kecil ibu memiliki pengetahuan gizi pada kriteria baik.

Rekomendasi untuk pihak kader dari setiap posyandu yang ada di Kelurahan Cimahi diharapkan dapat memberikan pendampingan lebih intensif pada ibu yang memiliki anak usia bawah dua tahun stunting, pendampingan tidak hanya saat kegiatan posyandu berlangsung. Diharapkan pendampingan yang dilakukan dapat menambah pengetahuan ibu menjadi lebih baik terkait pengetahuan gizi seperti jenis zat gizi, fungsi zat gizi, sumber zat gizi, anjuran zat gizi serta dampak dari kekurangan gizi untuk mencegah anak mengalami terjadinya masalah gizi seperti stunting

\section{REFERENSI}


Hanum, F,dkk. (2014). Hubungan Asupan Gizi dan Tinggi Badan Ibu dengan Status Gizi Anak Balita. Jurnal Gizi Pangan, Vol.9, (1)

Kemenkes. (2016). Situasi Balita Pendek 2016. Jakarta

Laerani, dkk (2015). Hubungan Tingkat Pengetahuan,Sikap, Dan Perilaku Ibu Terhadap Konsumsi Zat Gizi (Energi, Protein) Pada Balita Gizi Kurang Di Desa Labuhan Lombok. Jurnal Media Bina Ilmiah, Vol.9, (1)

Nasikhah, R. (2012). Faktor Risiko Kejadian Stunting Pada Balita Usia 24-36 bulan di Kecamatan Semarang Timur. (Skripsi). Universitas Diponogoro

Ni'mah, K, dkk. (2015). Faktor yang Berhubungan dengan Kejadian Stunting Pada Balita. Jurnal Media Gizi Indonesia, Vol.10, (1)

Ramlah. (2014). Gambaran Tingkat Pengetahuan Ibu Menyusui Tentang Stunting Pada Balita Di Puskesmas Antang Makassar Tahun 2014. (Skripsi). Universitas Islam Negeri Alauddin Makassar

Sujarweni.(2014). Metodologi Penelitian. Yogyakarta : Pustaka baru press.

Tanti,M. (2013). Hubungan Pengetahuan Gizi dengan Kebiasaan Makan Peserta Didik Kelas XI Jasa Boga SMKN 6 Yogyakarta. (Skripsi). Fakultas Teknik, Universitas Negeri Yogyakarta, Yogyakarta.

Tiwari, R, dkk (2014). Determinant of Stunting andsevere Stunting Among Under
Fives:Evidence from the 2011 Nepal.

Demographic and Health

Survey. BMC Pediatric 2014 14:239 DOI:10.1186.

Wahyuni, (2011). Hubungan Tingkat Pengetahuan Ibu Tentang MpAsi Dengan Pemberian Mp-Asi Pada Bayi Usia 6-12 Bulan Di Posyandu Pereng Bumirejo, Lendah Kulon Progo Yogyakarta Tahun 2011. (Skripsi). Sekolah Tinggi Ilmu Kesehatan Jenderal Achmad Yani.

Watania, dkk. (2016). Hubungan Pengetahuan Gizi Ibu dengan Kecukupan Asupan Energi Anak Usia 1-3 tahun di Desa Mopusi Kecamatan Lolayan Kabupaten Bolaang Mongondow Sulawesi Utara. Jurnal e-Biomedik, Vol. 4, (2) 